\title{
Annual development of climatic summer in northern North America: accurate prediction of summer heat availability
}

\author{
Peter A. Scott \\ Department of Zoology, University of Toronto, Toronto, Ontario, Canada M5S 1A1
}

\begin{abstract}
The development and stability of climatic summer in northern latitudes is examined. Initially, the southern limit of the Arctic Air Mass is delineated by the Arctic Front. The poleward retraction of the Front is quantified by a temperature discontinuity that occurs after the last day that the $05: 00 \mathrm{~h}$ (CST) temperature is at or below $2^{\circ} \mathrm{C}$. Then it is postulated that the force of poleward propagation of warm tropical air, and thus the subsequent summer heat availability, is indicated by the thermal gradient across the passing Arctic Front. The thermal gradient hypothesis is tested by quantifying the spring passage of the Arctic Front and predicting subsequent summer heat availability during the 1980-90 period at 3 locations in northern Canada (tundra, treeline, and forest). Far beyond the treeline at the tundra site, the Frontal pass is an infrequent event, climatic summer does not usually occur, and there is therefore no accurate predictor of summer heat availability $(r=-0.3756 ; p>0.05)$. At the treeline site, the temperature gradient measured across the Arctic Front during passage is an accurate predictor of subsequent summer heat availability $(r=0.9679 ; \mathrm{p}<0.01)$. In the northern Boreal forest location, with some diversity of southern air mass influences, air mass retraction is also an accurate predictor of the summer heat availability $(r=0.9863$ and $r=0.8749 ; p<0.01$ and $p<0.05$ for warm and cold summers respectively). It is speculated that deterministic climatic events such as demonstrated here may also play a role in the synchrony of subsequent brological events, tor example the timing of insect development and pollination in flowering plants. This study is apparently the first to objectively define and clearly illustrate the role of the Arctic Front in the development of summer. Further, this is the first analysis that demonstrates that the Frontal gradient at the edge of the retracting Arctic Air Mass can accurately predict subsequent summer temperatures. Growing season degree days may be predictable in areas that are periodically dominated by the Arctic Air Mass including the agricultural areas of Canada and the northern United States.
\end{abstract}

\section{INTRODUCTION}

The development of summer in northern regions is usually an annual occurrence. However, there is increasing awareness that catastrophic events such as the eruption of Tambora in 1815 can influence and even prevent the occurrence of summer in mid-latitudes (Harington 1992, and references therein). Further, shifting circulation patterns are sufficient to prevent the occurrence of summer for many decades in the northern boreal forest as happened, for example, during the Little Ice Age (Scott et al. 1988), or to cause climatic summer to occur in polar deserts where it is atypical. It is important to understand the development and stability of circulation patterns associated with the occurrence of climatic summer.
Under baseline conditions in circumpolar ecosystems ambient temperatures are often below the freezing point of water. In response to orbital variations, annual warming occurs in polar latitudes largely due to poleward propagation of heat energy from equatorial regions (Anderson \& Stevens 1987) and increased radiation (Hare \& Ritchie 1972, Barry et al. 1981). Spring is commonly referred to as the post-winter period of increasing daylength between the beginning of snowmelt and the last seasonal frost. Although the seasonal increase in daylength is consistent from year to year, one of the changing variables in spring is the rate and degree of warming. During spring, temperate air masses begin to influence near-ground conditions when the Arctic Air Mass contracts poleward (Bryson 
1966, Barry 1967). Since the warm and cold air masses have different densities, poleward propagation of warm air results in the temporary displacement of winter conditions (Bryson 1966). The southern edge of the Air Mass is often characterized by an abrupt 'break' (Oerlemans 1978) or 'discontinuity' (Kalnicky 1987) in the temperature regime that is especially prominent at surface level (Penner 1955, Kirk 1966). This shift, from cool to much warmer near-ground temperatures, delineates the Arctic Front (Barry 1967) and marks the beginning of summer (Kalnicky 1987). Summer is often defined as the period when the poleward intrusion is sufficient to maintain ambient temperatures consistently above the freezing point of water.

During winter, water is found in solid form and terrestrial organisms, which are mostly composed of water, either remain dormant or generate a supply of heat to maintain their water in a liquid state. As warming begins, other terrestrial organisms migrate in from more temperature latitudes and, in addition to maintaining an active metabolism, growth and reproduction are enabled. Consequently, the passing of spring coincides with the initiation of biological processes connected with growth and reproduction including flowering (Rathcke \& Lacey 1985, Andersen 1991), bud swell in trees (Scott et al. 1987. Hanninen 1990) goose migrations (Blokpoel \& Gauthier 1975, Davies \& Cooke 1983) and nesting (Sedinger \& Raveling 1986 MacInnes et al. 1990), and the nesting of birds in general (Jehl \& Smith 1970)

On several occasions during late winter in the 1980s, I observed many thousands of staging Canada and Snow Geese leave the coast of Hudson Bay near Churchill, Manitoba (Canada) and fly north. In each case, the geese departures coincided with 'rains' of mature insects and also preceded a large increase in ambient temperature. Geese are known to migrate north on southerly winds (Blokpoel \& Gauthier 1975), however a source for mature insects would have been nearly $1000 \mathrm{~km}$ to the south indicating that these southerly winds were part of a large-scale atmospheric circulation phenomenon. Apparently I may have observed the passing of the Arctic Front over Churchill (Fig. 1), and this passing was possibly a cue to the initiation of many diverse biological events. For example, the departing geese would migrate north $1000 \mathrm{~km}$ over sea ice into an apparently unknown environment (Blokpoel \& Gauthier 1975, Davies \& Cook 1983). On arrival a nest would be built during winter conditions, eggs would be laid, and the critical hatch period would occur in a set number of days (Ankney \& Bisset 1976 , Findlay \& Cooke 1982). The hatch period normally coincides with the maximum nutrient concentration in forage species (Sectinger \& Raveling 1986).
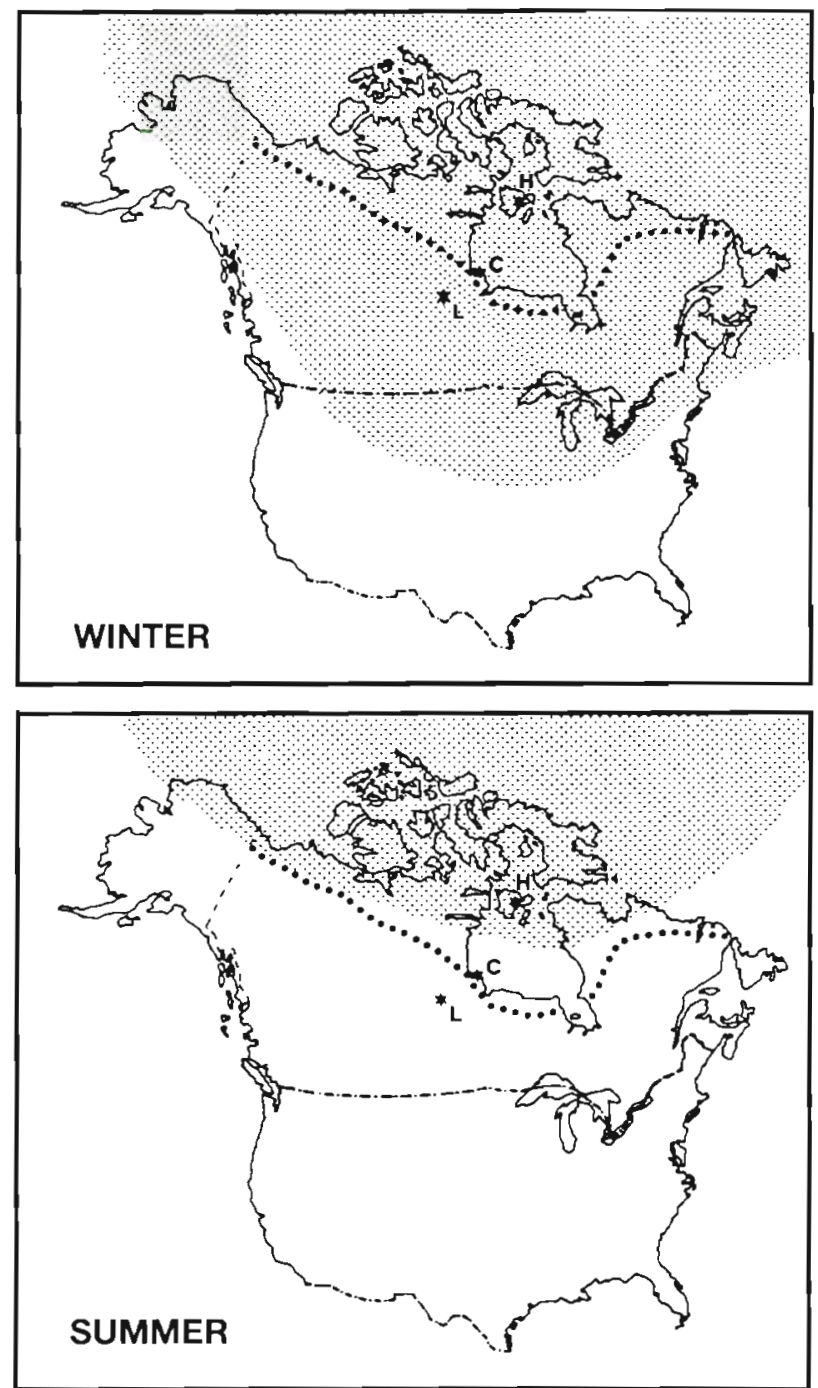

Fig. 1 Map of North America showing the location of Lynn Lake (L), Churchill $(\mathrm{C})$ and Coral Harbour $(\mathrm{H})$ relative to the approximate location of the treeline (dotted line) and the Arctic Air Mass (stippled) during winter and summer (after Barry 1967 for the 1961-65 period). From winter to summer, the Arctic Front as the southern edge of the Air Mass moves north over northern North America creating a temperature discontinuity when passing over surface locations

After the start of reproductive activities in spring then, the survival and perpetuation of populations may depend on the successful outcome of coupled processes (Smith 1966). Unforeseen events that occur during reproductive efforts may alter the timing of some activities, but synchronized outcomes between independent processes require that the organisms involved be largely insensitive to unpredictable variation, or canalized (Rathcke \& Lacey 1985). For example, in many species flowering must coincide with the independent development of insects needed for pollination (Rathcke \& Lacey 1985). The evolution 
of such synchronized biological events would be dependent on environmental cues that trigger the synchrony. The observed response of geese to seasonal changes in atmospheric circulation indicates that deterministic chaos (Ives 1991), such as characterized by weather and climate processes (Nicolis \& Nicolis 1984 , Essex et al. 1987), may have predictive value which is demonstrated by the survival and perpetuation of natural populations.

The initial purpose of this study is to identify, define. and quantify the temperature event associated with the observed insect 'rains' and goose migrations in the context of the 3-front circulation model (Penner 1955, Galloway 1958, Bryson 1966, Barry 1967). The annual development of summer is objectified by delineating the Arctic Front. The dynamics of the contracting Arctic Air Mass near the surface are then examined and a mechanism is proposed to explain how summer develops.

The other purpose of this study is far more tenuous. I examine the possibility that the Frontal pass may play a role in synchrony of the outcome of biological events. For this to be possible, predictive information must also be available from the Frontal pass. I test for predictive information by predicting future summer temperatures using the thermal characteristics of the Arctic Front.

\section{METHODS AND RESULTS}

\section{Field sites and weather data}

The analyses of weather data included data from 3 locations for which extensive temperature records were available. The initial study of the development of summer was based on temperatures over an $11 \mathrm{yr}$ period, from 1980 through 1990, at Churchill, Manitoba, Canada $\left(58^{\circ} 45^{\prime} \mathrm{N}, 94^{\circ} 04^{\prime} \mathrm{W}\right)$ where I noted the weather events under investigation. Churchill is located on the southwest coast of Hudson Bay within the forest-tundra ecotone (Fig. 1). Further investigations were undertaken using temperature data from Coral Harbour $\left(64^{\circ} 11^{\prime} \mathrm{N}, 83^{\circ} 12^{\prime} \mathrm{W}\right.$ ) in the Northwest Territories, a mid-arctic location some $850 \mathrm{~km} \mathrm{NE}$ of Churchill, in the northern sector of Hudson Bay. Summer periods free from the dominance of the Arctic Air Mass are infrequent at Coral Harbour and, therefore, the Arctic Front does not always pass this location (Bryson 1966, Barry 1967). A third study used temperature data from Lynn Lake, Manitoba $\left(56^{\circ} 52^{\prime} \mathrm{N}\right.$, $101^{\circ} 04^{\prime} \mathrm{W}$ ), a boreal forest location some $470 \mathrm{~km}$ WSW of Churchill. Lynn Lake is an inland site well-removed from the maritime influence of Hudson Bay. Hourly temperature data and monthly weather summaries for the 3 sites as well as additional information on snow cover, precipitation, wind speed and direction for Churchill were provided by Environment Canada.

\section{Locating the Arctic Air Mass}

To determine the retraction of the Arctic Air Mass as it passes over Churchill, I graphed hourly temperature values in series covering May to September for each hour of the day, and for each of the 11 yr. The graphs were then examined visually for an annual repetition of abrupt breaks or discontinuities in temperature. The graphs indicated that a shift in temperature patterns was clearest under early morning conditions and hence, the temperature at 05:00 h (CST) was selected for use. After the temperature discontinuity, 05:00 h temperatures were consistently above $2^{\circ} \mathrm{C}$ during all 11 yr under study. Rather than choosing only those years in which the discontinuity was clearly evident (e.g. 1989; Fig. 2) the beginning of summer was defined as the last day in spring when the temperature at 05:00 h was $2.0^{\circ} \mathrm{C}$ or lower. This ensured that each year was treated in the same way, regardless of the pattern of the temperature discontinuity. In practice, this approach agrees with the 9 yr where the discontinuity in temperature was obvious and also includes the 2 cold years $(1980,1986)$ where it was less evident.

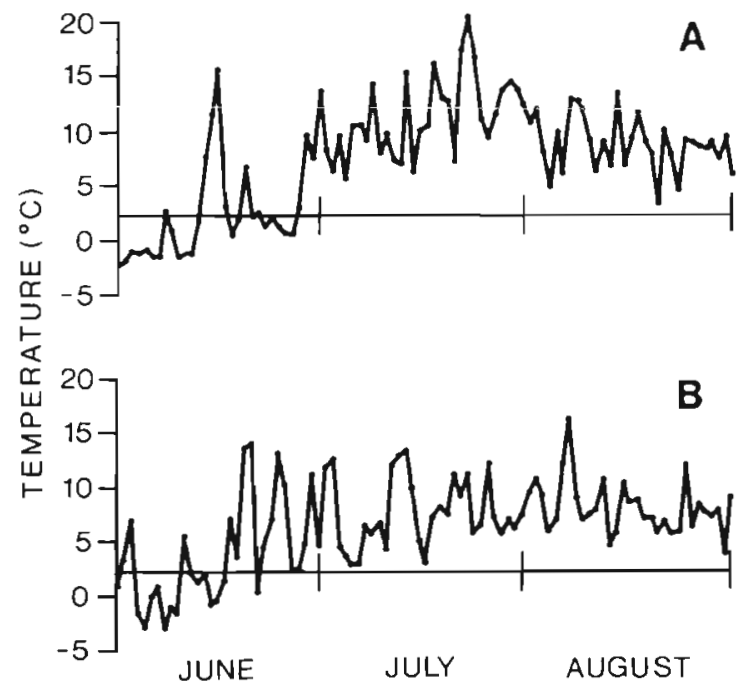

Fig. 2. Series of 05:00 h temperatures during June, July, and August at Churchill, Manitoba, for a typical year (1989, A) and the coldest year during this study $(1986, \mathrm{~B})$. Characteristic of the passage of the Arctic Front, a statistically significant change in the temperature regime is evident on June 27, 1989 Although obscured by the influence of sea-ice during 1986 , June 22 marks the last day the temperature was below $2{ }^{\circ} \mathrm{C}$ which coincides with the change in temperature regime. While the Arctic Air Mass no doubt continues to influence temperatures throughout the summer, it is no longer the dominant air mass in the region 


\section{Delineating the Arctic Front}

To define the minimum number of days required to characterize the discontinuity (Oerlemans 1978) that evidently exists at the southern edge of the Arctic Air Mass, the variability in weather patterns was examined and characterized. The weather systems, relative high and low pressure systems that pass through Churchill, persist on average for slightly more than $3 \mathrm{~d}$. At the minimum, 3 weather patterns that occur immediately before the passing of the Front should include at least 2 cold weather systems. Conversely, the 3 weather patterns immediately after the passing of the Front should include at least 2 warm periods. To include 3 such weather systems, the Frontal gradient was initially quantified using $10 \mathrm{~d}$ periods, but later correlations with summer temperature suggested the use of $11 \mathrm{~d}$ periods (Fig. 3).

To test the significance of the discontinuity for each of the $11 \mathrm{yr}$, the variances for the two $11 \mathrm{~d}$ periods around the passing of the Front were initially compared pairwise and found to be homogeneous (Sokal \& Rohlf 1981). The temperature means for $11 \mathrm{~d}$ prior to the Frontal pass were then compared with the temperature means of the $11 \mathrm{~d}$ following the passing of the Front using $t$-tests (Sokal \& Rohlf 1981, Knox et al. 1988). All of the pairs tested were significantly different $(p<0.01)$, except that for the coldest year, 1986, which did not show a significant change $(p>0.05)$ based on a comparison of temperatures for the two $11 \mathrm{~d}$ periods

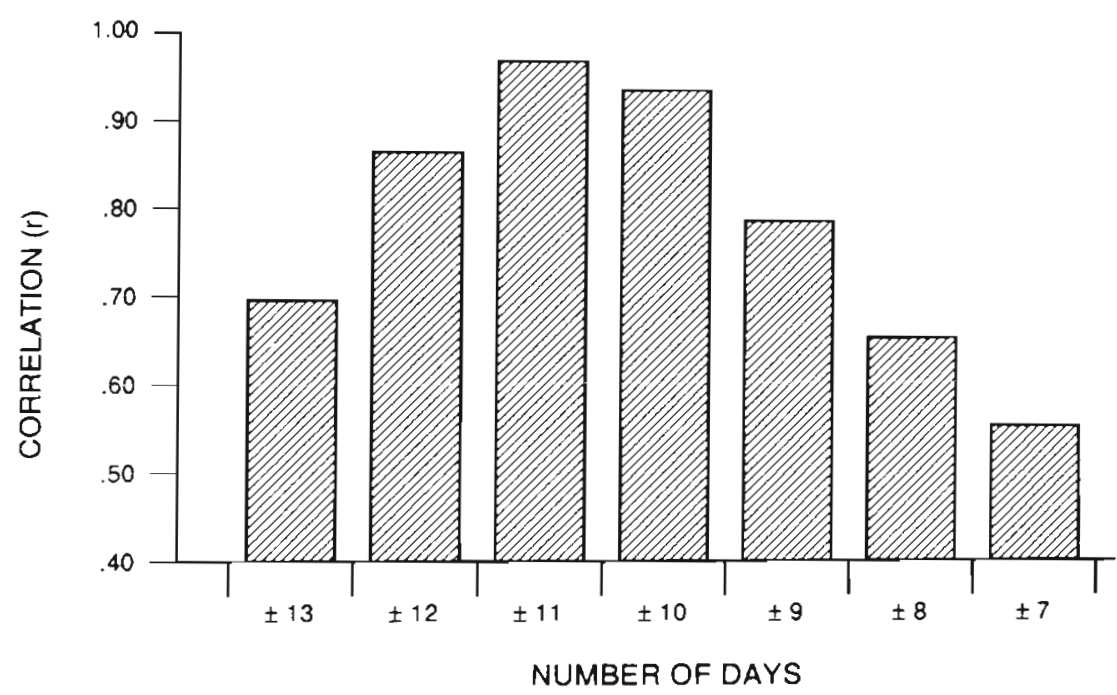

Fig. 3. Correlation coefficients for the prediction of summer temperature (July and August) using the average difference in $05.00 \mathrm{~h}$ temperatures before and after the annual spring passing of the Arctic Air Mass over Churchill from 1980 through 1990. The abscissa represents a different number of days used to define the average 05:00 $\mathrm{h}$ temperatures. The best correlation occurs when using $11 \mathrm{~d}$ average periods
Table 1. Date, initial $11 \mathrm{~d}$ temperature average $\left(T_{\mathrm{SP}}\right)$, final $1.1 \mathrm{~d}$ temperature average $\left(T_{S U}\right)$, the temperature increase $(\Delta T)$ around the thermal discontinuity that marks the passing of the Arctic Front over Churchill, and the $t$-statistic from comparison of the annual means for $T_{\mathrm{SP}}$ with $T_{\mathrm{SU}}$. Temperatures in ${ }^{\circ} \mathrm{C}$

\begin{tabular}{|cccccc|}
\hline Year & Date & $T_{\mathrm{Sp}}$ & $T_{\mathrm{SU}}$ & $\Delta T$ & $t$ \\
\hline 1980 & June 26 & 3.00 & 6.88 & 3.88 & $2.975^{\circ}$ \\
1981 & June 18 & 0.03 & 6.88 & 6.85 & $6.658^{\circ}$ \\
1982 & June 28 & 2.51 & 6.05 & 3.54 & $2.847^{\circ}$ \\
1983 & June 15 & 0.32 & 5.60 & 5.28 & $3.710^{\circ}$ \\
1984 & June 21 & 3.55 & 9.29 & 5.75 & $3.483^{\circ}$ \\
1985 & June 10 & 0.26 & 4.29 & 4.03 & $4.663^{\circ}$ \\
1986 & June 22 & 3.95 & 7.55 & 3.60 & 1.853 \\
1987 & July 02 & 3.07 & 7.13 & 4.05 & $4.267^{\circ}$ \\
1988 & July 13 & 4.66 & 10.30 & 5.64 & $4^{\circ} .787^{\circ}$ \\
1989 & June 27 & 1.90 & 8.36 & 6.46 & $6.551^{\circ}$ \\
1990 & June 29 & 3.79 & 8.60 & 4.81 & $4.569^{\circ}$ \\
Avg. & June 23 & 2.45 & 7.35 & 4.90 & \\
'Significant difference $(\mathrm{p}<0.01)$ & & \\
\hline
\end{tabular}

(Table 1). The years in which warmer temperatures prevailed following the passing of the Front had a greater temperature gradient across the Front and were most significantly different (i.e. the highest $t$ values).

On average, passage of the Arctic Front over Churchill occurred on June 23. The earliest date of the Frontal pass was June 10 and the latest date was July 13. These dates closely correspond to the last day of spring frost which is a significant phenological event for example for hatching birds and growing trees. The Front usually passes after the main period of snowmelt in this region (Churchill Weather Office, Rouse 1991, pers. obs.) and before the break-up of the Hudson Bay ice cover (Rouse 1991, pers. obs.). In relation to snow cover and the presence of sea ice, however, there was no correspondence with the thermal discontinuity evident over the 11 yr of the study, although the cooling influence caused by the presence of sed ice was demonstrated on one occasion (see below). The discontinuity in temperature is evidently the passing of the Arctic Front as it defines the southern limits of the Arctic Air Mass during poleward contraction in the spring. While the Air Mass will no doubt continue to influence summer temperatures, it will no longer dominate the study area until the expansion of the Arctic Air Mass in autumn. 


\section{Gradient across Arctic Front predicts summer temperature at treeline}

The intensity of the poleward propagation of summer heat may be indicated by the thermal gradient present as the Arctic Front retracts over a specific location. This gradient would be proportional to the strength of the tropical forcing, and indicate how far the Front will travel north, and also how long the Front will remain north of the location. The distance and duration of the Frontal movement will determine the intensity and duration of heat or the summer heat availability (Angell 1992)

To quantify the size of the temperature discontinuity or the thermal gradient across the passing Arctic Front $(\Delta T)$ the following equation was used;

$$
\Delta t=\left(\overline{T 05}_{\text {SUMMER }}-\overline{T 05}_{\text {SPRING }}\right) / D
$$

where $\overline{T 05}_{\text {SUMMER }}$ is the average 05:00 $\mathrm{h}$ temperature for the $11 \mathrm{~d}$ period immediate following the temperature discontinuity; $\overline{T 05}_{\text {SPRNG }}$ is the average 05:00 $\mathrm{h}$ temperature for the $11 \mathrm{~d}$ period immediate before the temperature discontinuity; and $D$ is the number of days over which the discontinuity occurs. In this study, $D=1$

Passage of the Arctic Front over Churchill was evident as a temperature increase of $4.9^{\circ} \mathrm{C}$ (Table 1). During the $11 \mathrm{yr}$ period, the 11 d spring temperatures ranged from near $0{ }^{\circ} \mathrm{C}$ to almost $5^{\circ} \mathrm{C}$. The $11 \mathrm{~d}$ summer temperatures ranged from near $4{ }^{\circ} \mathrm{C}$ to more than $10^{\circ} \mathrm{C}$. Multiple paired correlations (Sokal \& Rohlf 1981) between the $11 \mathrm{~d}$ temperatures before and after the discontinuity, and with the temperature change were not significant. During the 11 yr of the study, the size of the discontinuity is apparently independent of the initial $11 \mathrm{~d}$ spring temperatures $(r=-0.2710, p>0.05)$ and the final $11 \mathrm{~d}$ summer temperatures are also independent of the size of the discontinuity ( $r=$ $0.4236, p>0.05$ ). Consequently, the $11 \mathrm{~d}$ summer temperatures after the discontinuity are independent of the initial spring temperatures although warm springs seem to relate somewhat to warm summers $(r=0.7570, p>0.05)$.

To relate the passage of the Arctic Front over Churchill to summer heat availability, I regressed the temperature gradient across the Arctic Front linearly against the summer temperature (Fig. 4)
The summer period at Churchill was defined to be July and August. During the years examined, the mean summer temperature ranged from 10.4 to $13.6^{\circ} \mathrm{C}$ with an average of $11.89^{\circ} \mathrm{C}$. The temperature gradient measured across the Arctic Front during the poleward retraction of the Arctic Air Mass in spring is demonstrated to be a highly accurate predictor $\left(\mathrm{R}^{2}=0.9368\right)$ of mean summer temperatures near the treeline at Churchill (Table 2). The temperatures during the individual spring and summer $11 \mathrm{~d}$ periods did not correlate significantly with the mean summer temperatures $(r=-0.2483$ and $r=0.4229$ respectively).

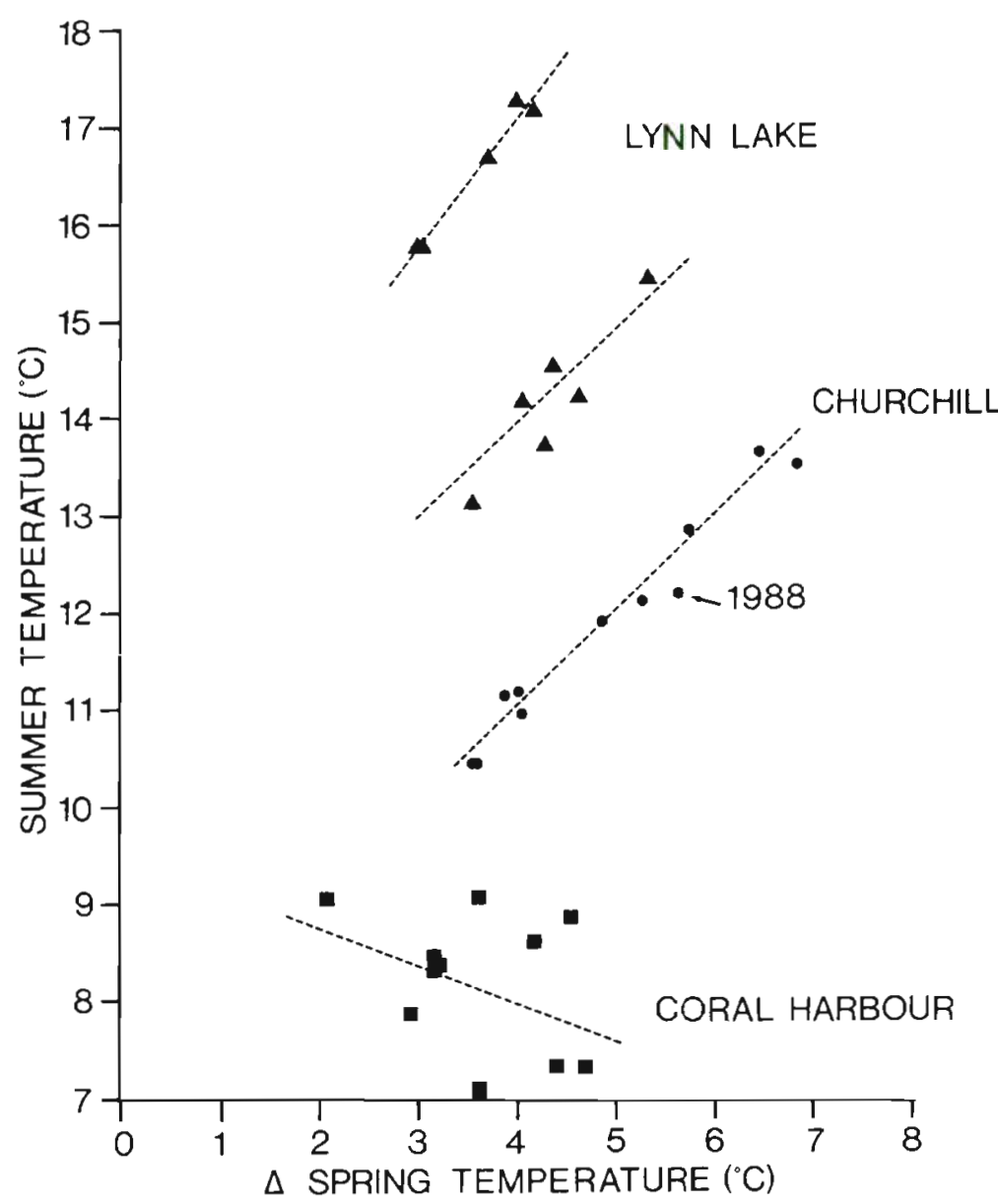

Fig. 4. Regressions of the change in temperature that occurs with the passing of the Arctic Front in spring with summer temperature (July and August). At Coral Harbour where the correlation is not significant, the Front infrequently passes and then only for short period. At Churchill the correlation is highly significant, although occasional deviations occur largely from the suppression of summer temperatures by Hudson Bay sea ice (e.g. 1988) At Lynn Lake, there are 2 distinct types of summers. The cool summers end during the last week of August leading to a somewhat noisy, though still significant correlation. The warm summer type of years at Lynn Lake also have a highly significant correlation. From this graph and Table 2 it is evident that summer temperatures can be accurately predicted at the treeline and nearby sites as well 
Table 2. Location, ecoregion, slope and intercept of linear regression for size of discontinuity versus summer temperature, correlation coefficients ( $r$ ), and the number of years $(n)$ in each analysis for the 4 data sets from 3 locations

\begin{tabular}{|c|c|c|c|c|c|c|}
\hline Location & Latitude & Ecoregion & Slope & Intercept & $\mathrm{r}$ & $\mathrm{n}$ \\
\hline Lynn Lake (warm) & $56^{\circ} 52^{\prime}$ & Boreal & 1.3111 & 11.80 & $0.9863^{\circ}$ & 5 \\
\hline Lynn Lake (cold) & $56^{\circ} 52^{\prime}$ & Boreal & 0.9558 & 10.08 & $0.8749^{\circ}$ & 6 \\
\hline Churchill & $58^{\circ} 45^{\prime}$ & Subarctic & 0.9886 & 7.09 & $0.9679^{\cdots}$ & 11 \\
\hline Coral Harbour & $64^{\circ} 11^{\prime}$ & Arctic & -0.3432 & 9.43 & -0.3756 & 11 \\
\hline
\end{tabular}

\section{Northern boundary of climatic summer}

At Coral Harbour, cool temperatures persist during the summer as the Arctic Air Mass dominates weather patterns all year. For example, the range of July temperatures during the $11 \mathrm{yr}$ of study was 8.3 to $11.5^{\circ} \mathrm{C}$ with a mean of $9.25^{\circ} \mathrm{C}$; August temperatures were much cooler than mean July temperatures. The analysis using hourly temperature data for Coral Harbour for the same period (1980-90) revealed that the July temperature was consistently above $2{ }^{\circ} \mathrm{C}$ in only 2 of $11 \mathrm{yr}$, and in no year was the temperature consistently above $2^{\circ} \mathrm{C}$ when temperature data for July and August were combined. Consequently, regressions based on either mean summer temperatures (Fig. 4) or just mean temperatures for July (not shown) were no significant because the Frontal pass did not occur each year (Table 2). Thus, the occurrence of summer conditions was unpredictable at Coral Harbour.

\section{Summer in the boreal forest}

Hourly temperature data for Lynn Lake reveal 2 distinct patterns of summer temperatures. Hot summers occurred during 1981, 1983, 1984, 1988, and 1989 and averaged at $16.50^{\circ} \mathrm{C}(\mathrm{SD} \pm 0.73)$. The other summers between 1980 through 1990 were $2.25^{\circ} \mathrm{C}$ cooler on average $(14.27 \pm 0.67)$. A statistical comparison between these averages confirms that the two are significantly different $\left(t_{\mathrm{S}}=5.2815 ; \mathrm{p}<0.001\right)$ (Knox et al. 1988). There is no distinction in amounts of precipitation between the 2 types of summers, although examination of the synoptic patterns (Climate Perspectives 1980-90) reveals that warm years are characterized by warm air input from the Pacific Ocean, as described by Bryson (1966). A similar synoptic pattern also occurs for the coldest summer (1982) which coincides with an ENSO (El NiñoSouthern Oscillation event; Kousky 1987). Other air masses that contribute to the cooler summers in the region are described by Bryson (1966; see also Climate Perspectives 1980-90). Consequently, temperature data for warm summers were separated from corresponding temperature data of cooler summers when regression and correlation analysis were being carried out.

During the years of hot summers, the temperature change at the end of spring at Lynn Lake was smaller than that at Churchill but the magnitude of the change accurately predicted $\left(R^{2}=0.9727\right)$ the mean, combined July and August temperature (Fig. 4). During the years when cool summers prevailed the prediction was less accurate $\left(R^{2}=0.7654\right)$, because the cool fall weather began in the last week of August creating variability in the average July and August temperatures. However, with both regressions, the results are still significant (Table 2).

\section{Sea ice influence}

The cooling influence of Hudson Bay sea ice has been well documented (Burbidge 1951, Rouse 1991). At Churchill, the high variability in the 05:00 h temperature that obscured the Frontal pass in 1986 resulted from the influence of sea ice. This phenomenon also best explains the following inconsistency. On 22 June 1988, the Front passed over the southern site at Lynn Lake, while 2 d later, on 24 June, the Front apparently passed over the northern site at Coral Harbour. However, a clear discontinuity in the temperature at 05:00 h occurred on July 13 at the Churchill location (Fig. 5). Fig. 5B shows the occurrence of unusually high variability in the temperature at 05:00 h during the last half of June and until July 13, associated with shifting winds linked with the presence of sea ice (Rouse et al. 1989, Weick \& Rouse 1991). After the passing of spring there is usually an increase in the difference between temperatures at 05:00 h and those at mid-day, which did not occur at Churchill. Before June 22 the decaying Hudson Bay ice pack had built up along the coast at Churchill. As southerly winds pushed the ice out, the air temperature increased. When the winds subsided the ice returned on the water currents, cooling the land again. While the Arctic Air Mass may have retracted north of Churchill around June 22, a delay in the onset of summer condi- 


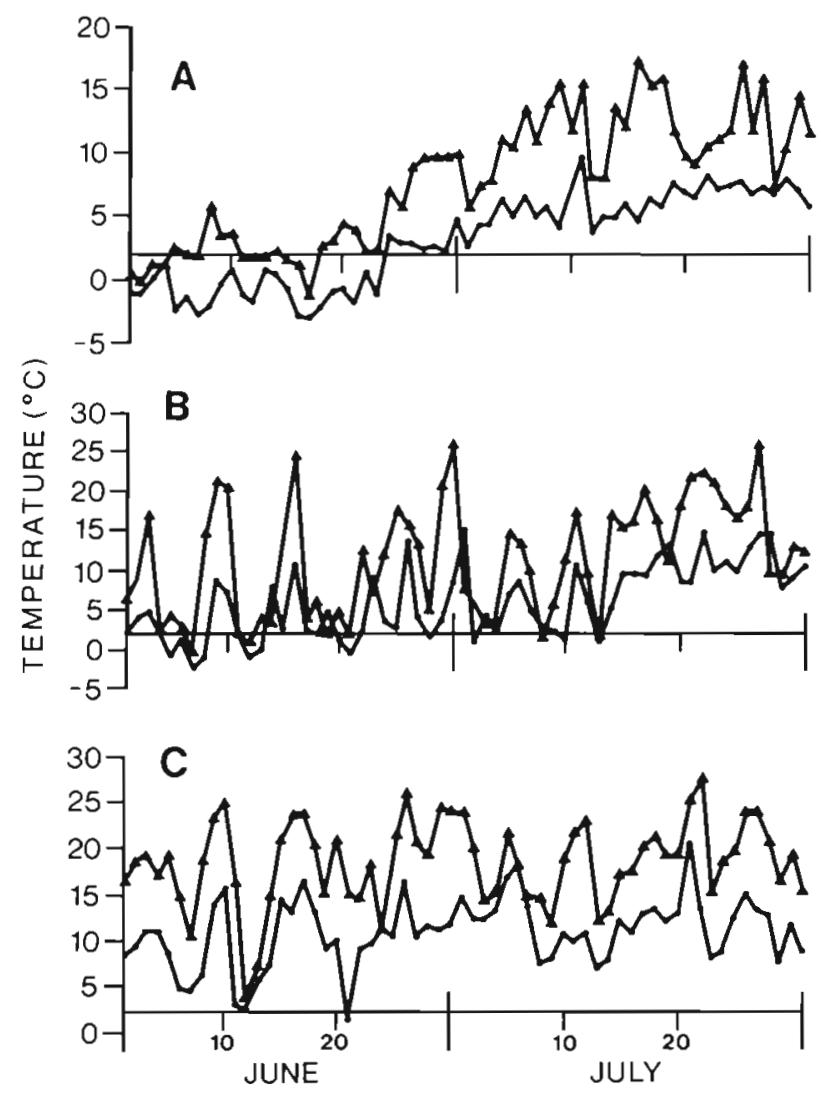

Fig. 5. The 05:00 (•) and 13:00 h (A) temperatures for (A) Coral Harbour, (B) Churchill and (C) Lynn Lake during 1988. The break that marks the passing of the Arctic Front occurs during June 21 at Lynn Lake and June 23 at Coral Harbour. However, at Churchill, the characteristic passing of the front is not evident until July 13. The suppression of summer conditions at Churchill was caused by the presence of Hudson Bay pack ice. During the latter half of June and the first half of July southerly winds blew the ice offshore dramatically raising the temperature. When the winds reversed, the onshore winds blowing across the pack ice cooled the land. The result was a period of high variability in the 05:00 h temperature and midday temperatures that are not always warmer than 05:00 h temperatures

tions was caused by this presence of Hudson Bay pack ice. The summer pattern did not begin at Churchill until after the pack ice was gone from the area on July 13. The same effect is not evident at Coral Harbour, because the pack ice generally breaks up and circulates south toward Churchill (Etkin 1991).

\section{DISCUSSION}

The spring retraction of the Arctic Air Mass can be characterized by the temperature discontinuity along its southern edge which is referred to as the Arctic Front. The passing of the Front coincides with an influx of heat that raises the ambient temperature and consistently maintains it above $2{ }^{\circ} \mathrm{C}$. This is a directly observable and measurable event that periodically changes a hostile environment, where most living organisms merely survive, into a thriving environment, where organisms grow and reproduce.

The thermal gradient across the Arctic Front is directly proportional to subsequent summer temperatures at the same location. If this gradient gauges the tropical thermal forcing that strongly influences the retraction of the Arctic Air Mass (Anderson \& Stevens 1987) and the ultimate distance traveled by the Arctic Front, then the maximum retraction of the Arctic Air Mass could be predicted (Angell 1992). The $y$-intercept from a linear projection for the regression of Frontal gradient versus subsequent summer temperature at Churchill is slightly more than $7^{\circ} \mathrm{C}$. That is, the summer temperature would be around $7^{\circ} \mathrm{C}$ if the Front did not pass. This is in fact the average temperature for Coral Harbour where the Front infrequently passes. Therefore, in a very crude way given the sparse climate data available for northern Canada, this study does demonstrate that poleward limits to the retraction of the Arctic Air Mass can be approximated from the thermal gradient across the Arctic Front as it passes the treeline

The evidence indicates that the occurrence of summer in northern latitudes is a perturbation caused by orbital variations which results in increased solar radiation in northern latitudes (Hare \& Ritchie 1972 , Barry et al. 1981) coupled with thermal forcing from equatorial regions as a result of a strong thermal gradient that would have developed over the previous winter. Consequently, the development of summer would be especially sensitive to reduction in radiation reaching the earth where both the radiation and the thermal gradient would be reduced. Slight differences in solar radiation, associated with sun spots for example (Angell 1992), could amplify in impact within northern ecosystems (Barry et al. 1981). Large volcanic eruptions such as Tambora in 1815 (Harington 1992) may dampen or mask the process without completely preventing the development of summer. Poleward propagation is moderated by air mass persistence as evident at Lynn Lake. Non-seasonal changes in air mass frequency are common in central North America (Bryson 1966) and their causes are often distant and obscure (Barry \& Perry 1973, Bradley \& England 1979 , Kalnicky 1987, Kousky 1987, Angell 1992).

Large-scale circulation patterns demonstrated in part by the dynamics of the Arctic Front are more persistent than are local weather conditions (Scott et al. 1988). Advance awareness of the summer conditions would be advantageous to organisms living in thermally marginal areas and should characterize adaptive 
strategies. For example, birds may choose not to nest instead of abandoning the nest after the eggs are laid. or reproductive buds in trees may remain dormant for another year rather than be initiated and fail. The cues for initiation of biological activities would be adaptive only if they enable synchrony at the end of processes, which then would contribute substantially to the overall success of the organisms. To deal with the stochastic events after initiation, behavioral repertoires and physiological tolerances would allow for a flexible response in most situations but make it very difficult to relate the cue of initiation to the successful outcome of the initiated process. In this paper, I have demonstrated that an observed cue, the passing of the Arctic Front in spring, also contains simple information that is a very good predictor of the subsequent summer heat availability. Such information would facilitate the development of the synchronized outcome of events that may be critical for survival of all species involved. The example of this observed yet unproved relationship between geese and their environment has enabled me to isolate and highlight the predictive information in the weather processes that was not obvious from the abiotic perspective alone.

\section{CONCLUSIONS}

Observations of staging geese along Hudson Bay revealed that migration flights corresponded to largescale atmospheric circulation. Furthermore, the initiation of these flights starts a process that will end with geese hatching at the same time as forage plants reach their maximum nutrient concentrations. For an atmospheric event to play a role in a synchronized outcome of 2 completely different and independent life forms, it is suggested that predictive informations must be apparent. To examine this hypothesis the annual development of summer was investigated for the 1980-90 period at an arctic site, at the treeline, and within the boreal forest.

Seasonal increases in incoming radiation and poleward propagation of tropical air contributes to poleward retraction of the Arctic Air Mass. As the Arctic Air Mass retracts during the spring warming phase, the last day when the temperature at 05:00 h (CST) is $2{ }^{\circ} \mathrm{C}$ or below usually delineates a naturally occurring, and statistically significant, temperature discontinuity at ground level; the passing of the Arctic Front. Poor correlations indicate that temperatures averaged for 11 d periods before and after passage of the Front appear independent of each other and of the size of the discontinuity. It is hypothesized that the strength of poleward propagation of the tropical air masses, and thus the summer heat that develops as a result, can be gauged by the thermal gradient across the Arctic Front. Poor correlations do exist between both the $11 \mathrm{~d}$ average temperatures before or after the Frontal pass and subsequent summer heat availability as defined by the mean temperature for July and August. However, highly significant linear correlations between the Frontal gradient and subsequent summer heat availability at the treeline, and at a boreal forest site, confirm this hypothesis.

Acknowledgements. Constructive advice and data were provided by J. M. Masterton, M. Webb, D. A. Etkin, and A. Shabbar at the Canadian Climate Centre, Downsview, Ontario, Canada. Helpful advice and comments on the manuscript were provided by R. G. Barry, I. Craine, D. C. F. Fayle, R. I. C. Hansell, R. L. Jefferies, B. Maxwell, T. S. Parsons, J. C. Ritchie, C. Rogers, W. R. Rouse and 3 anonymous referees. Funds were provided through the Natural Sciences and Engineering Research Council (\#A6505) and the Northern Scientific Training Program

\section{LITERATURE CITED}

Anderson, T. B. (1991). A model to predict the beginning of the pollen season. Grana 30: 269-275

Anderson, J. R., Stevens, D. E. (1987). The response of the tropical atmosphere to low frequency thermal forcing J. Atmos. Sci. 44:676-686

Angell, J. K. (1992). Relation between 300-mb North Polar Vortex and Equatorial SST, QBO, and sunspot number and the record contraction of the Vortex in 1988-89. J. Clim. 5: 22-29

Ankney, C. D., Bisset, A. R. (1976). An explanation of egg weight variation in the lesser snow goose. J. Wildl. Mgmt 40: $729-734$

Barry, R. G. (1967). Seasonal location of the Arctic Front over North America. Geogr. Bull. 9: 79-95

Barry, R. G., Courtin, G. M., Labine, C. (1981). Tundra climates. In: Bliss, L. C., Cragg, J. B., Heal, D. W., Moore, J. J (eds.) Tundra ecosystems: a comparative analysis Cambridge University Press, Cambridge, p. 81-114

Barry, R. G., Perry, A. H. (1973). Synoptic climatology. Methods and applications. Methuen, London

Blokpoel, H. Gauthier, M. C. (1975). Migration of Lesser Snow Geese in spring across southern Manitoba. Can. Wildl. Ser. Rep. Ser. 32

Bradley, R. S., England, J. \{1979\}. Synoptic climatology of the Canadian high arctic. Geografiska Annaler 61A: 187-201

Bryson, R. A. (1966). Air masses, streamlines and the boreal forest. Geogr. Bull. 8: 228-269

Burbidge, F E. (1951). The modification of continental polar air over Hudson Bay. Q. J R. Meteorol. Soc. 77. 365-374

Climate Perspectives, Vols. 2-12 (1989-90). Atmospheric Environment Service, Environment Canada, Toronto

Davies, J. C., Cooke, F. (1983). Annual nesting productivity in snow geese: praine droughts and arctic springs. J. Wildl. Mgmt 47:291-296

Essex, C., Lookman, T., Nerenburg, M. A. H. (1987). The climate attractor over short time scales. Nature 326: 64-66

Etkin, D. A. (1991). Break-up in Hudson Bay: its sensitivity to air temperatures and implications for climate warming Clim. Bul]. 25; 21-34 
Findlay, C. S., Cooke, F. (1982). Breeding synchrony in the lesser snow goose (Anser caerulescens caerulescens). I. Genetic and environmental components of hatch date variability and their effects on hatch synchrony. Evolution 36: $342-351$

Galloway, J. L. (1958). The three-front model: its philosophy, nature, construction and use. Weather 13: 3-10

Hanninen, H. (1990). Modelling bud dormancy release in trees from cool and temperate regions. Acta For. Fenn. 213: $1-47$

Hare, K. F., Ritchie, J. C. (1972). The boreal bioclimates Geogr. Rev. 62: 333-365

Harington, C. R. (ed.) (1992). The year without a summer? World climate in 1816. Canadian Museum of Nature, Ottawa

Ives, A. R. (1991). Chaos in time and space. Nature 353 $214-215$

Jehl, J. R., Smith, B. A. (1970). Birds of the Churchill Region, Manitoba. Manitoba Museum of Man and Nature Spec. Pub. No. 1

Kalnicky, R. A. (1987). Seasons, singularities, and climate changes over the midlatitudes of the Northern hemisphere during 1899-1969. J. Clim. appl, Meteorol. 26: 1496-1510

Kirk, T. H. (1966). Some aspects of the theory of fronts and frontal analysis. Q. J. R. Meteorol. Soc. 92: 374-381

Knox, J. L., Higuchi, K., Shabbar, A., Sargent, N. E. (1988). Secular variation of Northern Hemisphere $50 \mathrm{kPa}$ geopotential height. J. Clim. 1:500-511

Kousky, V. E. (1987). The global climate for December 1986-February 1987: El Niño returns to the tropical Pacific. Mon. Weather Rev. 115: 2822-2838

Lamb, H. H. (1982). Climate history and the modern world. Methuen, London

MacInnes, C. D., Dunn, E. H., Rusch, D. H., Cooke, F., Cooch, F. G. (1990). Advancement of goose nesting dates in the Hudson Bay Region, 1951-86. Can. Field Nat. 104: $295-297$

Editor: V. Meentemeyer
Nicolis, C., Nicolis, G. (1984). Is there a climatic attractor? Nature 311.529-532

Oerlemans, $J$ (1978). An objective approach to breaks in the weather. Mon. Weather Rev. 106: 1672-1679

Penner, C. M. (1955). A three-front model for synoptic analysis. Q. J. R. Meteorol. Soc. 81: 89-91

Rathcke, B., Lacey, E. P. (1985). Phenological patterns of terrestrial plants. Ann. Rev. Ecol. Syst. 16: 179-214

Rouse, W. R. (1991). Impacts of Hudson Bay on the terrestrial climate of the Hudson Bay Lowlands. Arct. alp. Res. 23: 24-30

Rouse, W. R., Hardill, S., Silis, A. (1989). Energy balance of the intertidal zone of western Hudson Bay II: Ice-dominated periods and seasonal patterns. Atmosphere Ocean 27 : $346-366$

Scott, P. A., Bentley, C. V., Fayle, D. C. F., Hansell, R. I. C. (1987). Crown forms and shoot elongation of white spruce at the treeline, Churchill, Manitoba, Canada. Arct. Alp. Res. 19: 175-186

Scott, P. A., Fayle, D. C. F., Bentley, C. V., Hansell, R. I. C. (1988). Large scale changes in atmospheric circulation interpreted from patterns of tree growth at Churchill, Manitoba, Canada. Arct. alp. Res. 20: 199-211

Sedinger, J. S., Raveling, D. G. (1986). Timing of nesting by Canada geese in relation to availability of their food plants. J. Anim. Ecol. 55: 1083-1102

Smith, J. M. (1966). The theory of evolution. Penguin Books, Baltimore, MD

Sokal, R. R., Rohlf, F. J (1981). Biometry. W. H. Freeman and Co., New York

Weick, E. J., Rouse, W. R. (1991). Advection in the Hudson Bay Lowlands, Canada. II. Impact of atmospheric divergence on the surface energy balance. Arct. alp. Res. 23 $338-348$

Manuscript first received: June 18, 1992

Revised version accepted: December 8, 1992 